\title{
La crítica neopragmatista de Rorty a la fundamentación discursiva de Habermas: Dos estrategias de legitimación democrática
}

\author{
Rorty's Neopragmatist Review to Habermas' Discursive \\ Fundamentation: Two Strategies of Democratic Legitimation
}

JAVIER RUIZ MOSCARDÓ*

\begin{abstract}
Resumen: El presente trabajo rastrea las principales objeciones que, diseminadas en diferentes lugares de su obra, realiza Richard Rorty contra Jürgen Habermas al respecto de la fundamentación de la política democrática. Tales críticas nos servirán para contraponer dos estrategias diferentes de legitimación democrática, coincidentes en su objetivo - la defensa de la socialdemocracia - pero divergentes en sus postulados - el neopragmatismo contra la racionalidad comunicativa. Leer a Habermas desde la óptica rortyana arroja luces sobre algunas nociones centrales de su doctrina y, al tiempo, ayuda a contextualizar y valorar su propuesta, confrontándonos con un problema crucial de la filosofía política actual: ¿necesita la política democrática una justificación racional? Palabras clave: Habermas, Rorty, filosofía política, democracia, neopragmatismo, liberalismo
\end{abstract}

\begin{abstract}
This paper aims to search for the principal objections that, disseminated around his work, Richard Rorty made against Jürgen Habermas about his democracy proposal. This critiques will serve us to compare two different strategies of democracy legitimation, coincident in their objective - the defense of social democracy - but divergent in their postulates - the neopragmatism against communicative rationality. Understanding Habermas from the rortyan point of view clarifies some central notions of his doctrine and, also, can help us to contextualize and judge his proposal, facing us with an important problem of nowaday's political philosophy: Is a rational justification necessary for democratic politics?
\end{abstract}

Keywords: Habermas, Rorty, political philosophy, democracy, neopragmatism, liberalism

Fecha de recepción: 28/03/2014. Fecha de aceptación: 17/06/2014.

* Investigador en Formación del programa FPU del Ministerio de Educación, Cultura y Deporte [FPU12/04046], adscrito al departamento de Metafísica y Teoría del Conocimiento de la Facultad de Filosofía y Ciencias de la Educación de la Universitat de València. Este trabajo se inscribe dentro del proyecto de investigación con financiación ministerial "Normatividad y praxis. El debate actual después de Wittgenstein” FFI2010-15975. Trabaja especialmente los campos de la Filosofía del Cine y Neopragmatismo y crisis de la Teoría del Conocimiento. Sus publicaciones recientes más destacadas son "Ni la presencia ni la ausencia': el concepto de representación y sus implicaciones”, en Agora: Papeles de filosofía, Vol. 35, N. 1, 2016, págs. 203-215, y “El cine, ¿puede hacernos peores? Stanley Cavell y el perfeccionismo moral”, ponencia presentada en el marco del III Simposio Internacional del Grupo USB-USAL, actualmente pendiente de publicación. Contacto: ruizmos2@uv.es 


\section{Introducción: La democracia en la "campana de cristal roja"}

En el curioso texto de Ludwig Wittgenstein "El ser humano en la campana de cristal roja" ${ }^{1}$ el austero filósofo de Cambridge compara las culturas con una estancia en la que la luz blanquecina del exterior, paradigma del Ideal Verdadero, se filtra al interior a través de cristales tintados de rojo. Una vez dentro, sus habitantes lo perciben todo en tonos rojizos, sin posibilidad, en principio, de advertir que allá afuera hay otro tipo de luz. Así, cuando alguien de la estancia alcanza sus bordes y cobra conciencia de que se encuentra constreñido en el discreto habitáculo de luz falseada, caben tres opciones: 1) seguirá como antes, pues tomará el choque como un mero roce con algún objeto interpuesto y no con el final del cuarto, 2) se resignará, sabedor de la imposibilidad de romper los límites de su habitación, y 3) intentará atravesar el cristal, en busca de la luz verdadera. Este último intento, al decir de Wittgenstein, está muy cerca de la ruptura religiosa; el segundo, por el contrario, viene acompañado de dos estados de ánimo que le ayudan a soportar mejor la roca de su parcialidad y contingencia, a saber: la melancolía y el humorismo. Lo primero sabe a utopía; lo segundo a resignación. Lo importante, en cualquier caso, es hacer notar que ambas actitudes implican la necesidad de habérselas con los límites, pues ya no cabe seguir viviendo como si no se hubiera llegado al extremo de la habitación.

Pues bien: en el presente trabajo pretendemos presentar a Jürgen Habermas como representante de la primera alternativa y a Richard Rorty como seguidor de la segunda. Lo que nos proponemos, en consecuencia, es rastrear las posibilidades de dos estrategias de refundación del liberalismo democrático que sí son conscientes de que están operando al límite de una cultura, y al tiempo investigar cuál pueda ser el papel del filósofo dentro de esta refundación. Lo haremos, además, siguiéndole los pasos a las críticas que Rorty lanzara al filósofo frankfurtiano, precisamente porque el núcleo de sus recriminaciones será la acusación de que Habermas persigue, en última instancia, la fusión con esa luz blanca y pura, símil de lo Incondicionado; y tal aspiración, lo adelantamos ya, puede ser contraproducente si de reafirmar los principios democráticos se trata.

\section{El "deseo universal de justificación" de Habermas}

Tal vez un buen punto de arranque consista en remontarnos, siquiera sea brevemente, a los orígenes del contractualismo clásico, pues consideramos que la estrategia habermasiana hunde sus raíces, tanto en aspiraciones cuanto en espíritu, en las prospecciones de aquel importante movimiento. A este respecto, podemos señalar lo que Rorty denominó el "deseo universal de justificación"2 como la característica fundamental del procedimiento teórico de los primeros contractualistas; procedimiento que, si llevamos a buen puerto nuestra empresa, el lector podrá reconocer en la doctrina habermasiana. Comencemos, pues, describiendo someramente las características de este particular deseo.

1 Editado en español en WITTGENSTEIN, L.: Luz y sombra. Una vivencia (-sueño) y un fragmento epistolar, trad. de Isidoro Reguera, ed. Pre-textos, Valencia, 2006.

2 Sobre esto, vid. "Universalidad y verdad", epígrafe n 3: verdad y justificación, en RORTY, R.: El pragmatismo, una versión, ed. Ariel, Barcelona, 2000, pág. 87 y ss. 
El procedimiento teórico de los padres del contractualismo incidió, como recurso infalible de convicción, en la idea de que los diferentes modelos contractuales que propusieran a la concurrencia debían estar correctamente justificados (esto es: la racionalidad de tales modelos debía ser evidente y su congruencia con la difusa noción de naturaleza humana bien asentada). Si esta hipótesis no va desencaminada, esto explica el constante énfasis de los primeros teóricos liberal-democráticos en postular un esquema acerca de la naturaleza humana y el desarrollo de su racionalidad capaz de validar las posteriores propuestas políticas: ya sea el miedo al estado de guerra que legitima el estado soberano de Hobbes, ya los derechos naturales del hombre natural lockeano, o ya la convención originaria de Rousseau que nos libra del señor - reconciliándonos en cierto grado con el buen salvaje que nunca nos abandonó del todo-, lo cierto es que ese deseo universal de justificación, incardinado en un modelo de racionalidad ávido de demostraciones y legitimaciones, fue una nota característica de los orígenes del pensamiento político moderno. Desde estas coordenadas, cabe subrayar el sentido particular de la justificación así entendida: una justificación que supone un determinado modelo de racionalidad humana con la cual debe concordar, apuntando a la idea ilustrada de un modo de organización social iluminado por la luz natural de la razón, destinada a incrustarse en las instituciones sociopolíticas.

De los distintos modelos contractuales conviene destacar la idea de "convención originaria" que esgrimiera Jean-Jaques Rousseau, puesto que no parece descabellado entender la estrategia de Habermas como una actualización de esta noción. Para el pensador ginebrino el estado social es irreversible; no sirve, como sucediera en Locke, proyectar un "estado de naturaleza" que actúe como contrapunto a las sociedades existentes, puesto que ese estado es para Rousseau inalcanzable e irrecuperable. La solución, por tanto, lejos de instituirse en un retorno a la libertad natural, consiste en sustituir una convención fáctica - fundada en la injusticia - por otra que lo sea de verdad: por una convención reflexiva que ponga en el poder a un nuevo "señor", ya fruto de la voluntad general, y que nos libere del antiguo déspota. De aquí surge la célebre idea de que la ley es la expresión de una voluntad general que no se equivoca nunca.

Dos siglos después, la estrategia habermasiana para actualizar la noción de voluntad general con el objetivo de limar sus posibles consecuencias totalitaristas - pues, ¿cómo tolerar la disensión y las alternativas individuales si esa voluntad se sacraliza y su no acatamiento supone un estigma? - será resaltar la vertiente formal de tal noción y convertirla en una guía que funde las condiciones de validez de las futuras máximas legales en las que se concrete. Así, en Aclaraciones a la ética del discurso, leemos que Habermas reclama validez para las normas si y sólo si éstas han recibido la aquiescencia de todos los afectados, en tanto que participantes simétricos de un proceso de comunicación carente de coerciones y sin más presiones que la del mejor argumento ${ }^{3}$. Oigamos la exposición del propio Habermas:

3 Conviene adelantar la crítica de Rorty a la idea de "mejor argumento", que se relacionará con el resto de nociones que critique: "la idea de un 'mejor argumento' tiene sentido sólo si uno puede identificar una relación de relevancia natural y transcultural, que conecte las proposiciones unas con otras formando algo similar al 'orden natural de la razón' cartesiano. Sin tal orden natural, sólo pueden evaluarse los argumentos por su eficacia en producir acuerdos entre personas o grupos concretos". RORTY, R.: "La justicia como lealtad ampliada", en Pragmatismo y política, ed. Paidós, Barcelona, 1998, pág. 122. 
"En las argumentaciones los participantes han de presuponer pragmáticamente que en principio todos los afectados participan como iguales y libres en una búsqueda cooperativa de la verdad en la que lo único que debe imponerse es la coerción del mejor argumento. Y en ese elemento pragmático-universal es en lo que se apoya el principio de la ética del discurso de que sólo pueden pretender validez aquellas normas que pudiesen encontrar el asentimiento de todos los afectados como participantes en un discurso práctico" 4 .

El movimiento habermasiano consiste, pues, en insertar la arcaica "voluntad general" de Rousseau en el enfoque de una ética formalista y procedimental: lo que legitima este proceder no es, como en el caso de Rousseau, el contenido de la norma (su sustancialidad, la ley), sino la validez de la misma, es decir, el modo en el que se ha acordado y consensuado. Si los afectados que han participado en el discurso dan su asentimiento a la norma como participantes libres del discurso, entonces se encuentra justificada. La clave consiste en que, al margen de este contexto de comunicación intersubjetiva, el principio se disuelve y se vacía: sólo es válido en relación a estos contextos discursivos, en tanto que condición necesaria para que la norma aspire legítimamente a ser universalizable. Lo que nos interesa subrayar de este somero resumen es que ser racional consiste precisamente en aceptar actuar de este modo en las discusiones; racionalidad y comunicación, pues, quedan urdidas en la misma trama (no en vano Habermas habla de la razón como razón comunicativa). Ahora, la justificación de la política democrática, ejemplificada en el modo de tomar las decisiones de esta nueva voluntad general trocada en razón comunicativa ejercida por los hablantes competentes y afectados, se basa en la apelación a un modelo de racionalidad procedimental en función del cual debe proyectarse cualquier organigrama social legítimo. Una justificación, como la de los antiguos contractualistas, que requiere en algún grado cierto margen de incondicionalidad, de universalismo, y de una estructura fija - ahistórica - de la razón humana. $\mathrm{O}$, al menos, de eso le acusará el pragmatista norteamericano.

\section{El punto de vista de la Razón Comunicativa: más allá de la persuasión}

Acabamos de señalar que la estrategia de Habermas para repensar y reactivar el modelo democrático consiste en rescatar esa voluntad justificadora tan propia de los primeros ilustrados que destacaba Rorty. Ahora debemos añadir que ese ímpetu de justificación es irrenunciable porque es necesario a la hora de convencer a la ciudadanía de que adopte el credo demócrata. Ahora bien, Habermas recelaría de que esta idea se interprete como un mero recurso retórico y persuasivo, pues tal movimiento restaría valor a la estrategia argumentativa; se trata precisamente de con-vencer, no sólo de vencer poéticamente. Hablamos, en definitiva, de dar una razón necesaria, relacionable con aquella vertiente más propiamente humana que confiere dignidad a nuestra especie ${ }^{5}$, y que no es sino su estructura racional-

4 HABERMAS, J.: Aclaraciones a la ética del discurso, trad. e introd. de Manuel Jiménez Redondo, ed. El Cid Editor [recurso electrónico de la biblioteca de la UV], Santa fe, 2004, pág. 28.

5 Nótense las claras resonancias kantianas de la propuesta. Esta ascendencia kantiana Rorty la resume como sigue: "Son las personas que piensan que existen cosas como una dignidad humana intrínseca, derechos humanos intrínsecos y una distinción ahistórica entre las exigencias de la moralidad y las de la prudencia 
comunicativa, incardinada ya en la publicidad de todo lenguaje. Podemos resumir este movimiento en la idea de que si prescindimos de un esquema normativo con pretensiones de universalidad, entonces resulta imposible convencer a la gente de que hay unas opciones mejores que otras y de que es posible preferir en función de reglas racionales ${ }^{6}$. El propio Habermas lo declara explícitamente:

“Cómo convenceríamos a la gente para que pusiera estas máximas [disminuir el sufrimiento humano, incrementar la igualdad entre los hombres] en práctica en comportamientos de carácter general si sólo podemos apelar a la promoción de la felicidad (...) en lugar de descubrir, desde un punto de vista moral, qué es correcto hacer? El punto de vista moral nos pide (...) luchar por el papel de un juez falible, pero imparcial, acerca de qué sería igualmente bueno para todos"7.

Nótese, en consecuencia, cómo Habermas es incapaz de concebir un modelo democrático que no apele a criterios incondicionados y universalistas, en gran medida porque ello redundaría en su rechazo por parte de la audiencia ${ }^{8}$. U ofrecemos un modelo de organización político que concuerde con la naturaleza racional de los seres humanos o no habrá posibilidad de que la democracia triunfe.

Ya este punto de partida será foco de las críticas de Rorty. Baste por el momento con decir que el núcleo de la crítica consiste en señalar la irrelevancia de lo que Rorty considera una mera estrategia de convicción. El autor pragmatista recela de que alguien se convierta al liberalismo democrático como una opción puramente teórica, tras descubrir que éste se halla más próximo del punto de vista moral o respeta las exigencias de la razón comunicativa. "Solamente un exceso de atención a la función declarativa - dice Rorty - podría hacernos

(...) a ellas se oponen quienes afirman que la 'humanidad' es una noción más biológica que moral, que no existe una dignidad humana no derivada de la dignidad de una comunidad concreta, y no puede apelarse a nada que vaya más allá de los méritos relativos de las diversas comunidades" (RORTY, R.: "Liberalismo burgués posmoderno", en Objetividad, relativismo y verdad, ed. Paidós, Barcelona, 1996, pág. 267). Rorty, huelga decirlo, se reconoce deudor de la segunda tradición, que remonta a Hegel. Por todo esto el pragmatista norteamericano acabará diciendo, no sin bastante interés provocativo, que "el problema de Habermas surge de tomarse a Kant demasiado en serio" (RORTY, R.: "Habermas y Lyotard sobre la posmodernidad", en Habermas y la modernidad, ed. Cátedra [colección teorema], Madrid, 1988, pág. 264).

6 Rorty se hace eco de esta percepción de Habermas: "el fin es evitar el relativismo que, en su opinión, sitúa a la política democrática al mismo nivel que la política autoritaria (...) considera importante poder decir que el primer tipo de política es más racional que el segundo" (RORTY, R.: "Universalidad y verdad”, en Objetividad, relativismo..., op. cit., pág. 83). Si no hay esquema normativo, la única alternativa que ve Habermas es un relativismo insalvable que culmina en la imposibilidad de legitimar en modo alguno el sistema democrático. Richard Rorty, lo adelantamos ya, propondrá una legitimación diferente pensada desde el relativismo como punto de partida, y no de llegada, como teme Habermas si triunfan las posiciones pragmatistas.

7 HABERMAS, J.: "El manejo de las contingencias y el retorno del historicismo", en Debate sobre la situación de la filosofía, editado por Jósef Niznik y John T. Sanders, ed. Cátedra (colección teorema), Madrid, 2000, pág. 41 .

8 Rorty lo explica con claridad encomiable: "Abandonar un punto de vista que es, si no trascendental, por lo menos 'universalista', le parece a Habermas que es como traicionar las esperanzas sociales que han sido centrales para la política liberal" ("Habermas y Lyotard...", en op. cit., pág. 225) La alternativa rortyana incidirá en que se puede ser perfectamente liberal sin poseer ningún tipo de noción universalista. 
creer que la pretensión de validez universal es importante para la política democrática" . En cambio, si uno acepta, con el pragmatismo de Rorty, que la función declarativa o enunciativa es sólo una de las varias funciones de un lenguaje concebido como caja de herramientas, no se entiende el porqué de priorizar esta función sobre el resto. Rorty acusa a Habermas, en consecuencia, de reproducir la imagen tradicional según la cual la característica central del sujeto es el conocimiento y, por ende, defender la imagen logocéntrica de lo humano (de forma paralela a como argumentará en su crítica a la epistemología clásica). Será la aceptación de esta exégesis antropológica lo que lleve a Habermas a la sobrevaloración de los esquemas normativos a la hora de promover la democracia. Por todo esto, la conclusión es que "Habermas rasca donde no pica"10.

No obstante, haríamos una mala interpretación de Habermas si no matizamos el esbozo que acabamos de presentar. Es cierto que Habermas está imbuido de esa pretensión de justificación propia de sus predecesores intelectuales, y no lo es menos que en ocasiones su discurso tiende a revalidar caducas concepciones metafísicas sobre la naturaleza humana y su racionalidad intrínseca. Pero la sutileza del pensamiento habermasiano es lo suficientemente amplia como para no conformarse con una repetición simplista de dogmas anticuados que él mismo critica. Pensamos sobre todo en su propuesta de una "ética de la intersubjetividad" que supere los enfoques egoístas del deleznable paradigma de la conciencia. Su punto de partida será el viraje desde la predominancia de las reflexiones acerca de la naturaleza y potencial de la conciencia hacia el paradigma del entendimiento intersubjetivo. Así, al quedar atrás un paradigma que precisa de una fundamentación sólida de la conciencia para resultar operativo, el nuevo método puede obviar ese tipo de justificaciones metafísicas y centrarse en el estudio del funcionamiento intersubjetivo del lenguaje. La razón tradicional, tornada subjetivista por la acción de la primacía de la conciencia, se ha convertido en razón comunicativa. Y esta razón comunicativa, en palabras de Rorty, consigue "dejar de lado la pregunta de si existe algún objeto metafísico con el que el resultado de dicha discusión se pudiera o no corresponder" 11 . De ahí que la finalidad de esta nueva concepción de la razón no sea, como en sus ilustres e ilustrados predecesores, la correspondencia con algún tipo de esencia humana que defina lo más característico de nuestra especie (como ocurría con los primeros contractualistas u ocurre con los filósofos subjetivistas de la conciencia); con Habermas, la justificación se alcanza por senderos bien distintos: "Concibo el entendimiento intersubjetivo como télos inscrito en la propia comunicación lingüística cotidiana (...) de un potencial operante ya siempre en la práctica comunicativa"12.

En lo que se centra este nuevo enfoque es, al decir de Rorty, "en tratar como verdadero lo que quiera que pueda ser objeto de acuerdo en el curso de una discusión libre"13. Aquí pensamos que esta idea habermasiana acerca de lo verdadero, que centra la especulación filosófica en el diálogo público e intersubjetivo -a diferencia de la mayoría de tradiciones epistemológicas que, Descartes mediante, han incidido en el carácter privado y autorre-

9 “Universalidad y verdad", en op. cit. pág. 84.

10 "Habermas y Lyotard...”, op. cit., pág. 259.

11 RORTY, R.: "Habermas, Derrida y las funciones de la filosofía”, en Verdad y progreso, [escritos filosóficos 3], ed. Paidós, Barcelona, 2000, pág. 343.

12 HABERMAS, J.: El discurso filosófico de la modernidad, ed. Taurus (Humanidades), Madrid, 1993, pág. 369.

13 "Habermas, Derrida..." en op. cit. pág. 343. 
flexivo de la verdad-, es una de las mejores muestras que ofrece el pensador alemán de autocomprensión ideal del modelo democrático-liberal. En efecto, no nos parece descabellado interpretar estas nociones de Habermas no como una descripción del funcionamiento general de todo lenguaje, basado en su lógica y estructura internas (aunque algo de ello, como diremos luego, aparezca en las tesis de Habermas), sino como una idealización del modo en que las democracias liberales operan. Y es que fueron precisamente las sociedades liberales, y el disenso que promocionaron acerca de las ultimidades existenciales de cada ciudadano, las que fundaron un modelo de comunicación en que la Verdad Una pudiera diluirse en diferentes y diversas opciones privadas; así, las reglas del juego de lo público, que ya no podían fundarse en revelaciones religiosas, al aceptarse el pluralismo imperante de opiniones y estilos de vida, no podían ser otras que las consensuadas colectivamente. La sustitución de revelación e imposición religiosas por el consenso intersubjetivo es precisamente lo que Habermas intenta elevar a principio racional por mor de que su nueva justificación de la política democrática resulte convincente. De ahí que uno de sus mayores esfuerzos consista en la aclaración de qué pueda significar una "comunicación no distorsionada", para que este consenso tan característico de las sociedades liberales no sea simplemente un barniz ideológico que maquille el triunfo del interés del más fuerte ${ }^{14}$.

Sin embargo, este retrato de Habermas sigue siendo parcial, pues el neófito pudiera interpretar, si se queda con nuestro esbozo, que la propuesta de Habermas puede enmarcarse en esos intentos pragmáticos por defender las sociedades liberales en función de su utilidad a la hora de resolver conflictos, aromatizado con algunos retazos de justicia para que las consecuencias indeseables de aquel principio benthamiano de "el mayor bien para el mayor número" no tengan cabida en el pensamiento democrático. Pero no. El de Habermas es un intento que adolece de algunas características del racionalismo tradicional, y ello será el blanco de las críticas rortyanas. Intentaremos demostrarlo resumiendo la importancia clave de la noción de "validez universal".

\section{La crítica pragmatista del concepto de "validez universal"}

El propio Rorty reconoce explícitamente que el centro de su discrepancia con Habermas se centra en esta noción, pues afirma que "las principales diferencias entre Habermas y yo conciernen a la noción de validez universal" 15 . Habrá que recurrir, pues, a las implicaciones de este importante concepto.

Rorty enmarca la validez universal habermasiana en la estela de pensadores como su colega Apel o Hillary Putnam. Estos filósofos se basarían, si la lectura rortyana es correcta, en la idea peirceiana de que la razón es normativa pero, sin embargo, esta normatividad puede tener cabida sin que se la naturalice, es decir, sin "un deber de correspondencia con

14 Rorty se hace eco de que la perspectiva habermasiana es, en el sentido que estamos subrayando, su tiempo en conceptos: "esta filosofía de la intersubjetividad gira en torno a una práctica característica de las sociedades liberales: tratar como verdadero lo que quiera que pueda ser objeto de acuerdo en el curso de una discusión libre" ("Habermas, Derrida...", en op. cit. pág. 343). Sirvan estas líneas de Rorty para mostrar, a su vez, que el pragmatista no se queda con una caricatura simplista del pensar habermasiano, sino que, además de tomarlo bien en serio, valora positivamente el nuevo enfoque comunicativo.

15 Debate sobre... op. cit. pág. 46. 
la naturaleza intrínseca de la realidad"16. En Facticidad y validez, Habermas expone esta concepción como sigue:

“La razón comunicativa posibilita, pues, una orientación por pretensiones de validez (...) se extiende por un lado a todo el espectro de pretensiones de validez, es decir, a la verdad proposicional, a la veracidad subjetiva y a la rectitud normativa", y esta pretensión de validez — añade más adelante - tiene "un momento trascendente de validez universal" 17

Se trata, como es de sobra conocido, de la célebre tesis según la cual la propia acción comunicativa contiene una serie de presuposiciones de carácter universalista. Hay, en consecuencia, una racionalidad inmanente a las prácticas discursivas que se centra en el hecho de que para lograr un acuerdo, basado en el entendimiento mutuo, los hablantes competentes exhiben pretensiones de validez en sus discursos y argumentaciones. Claro que esta tesis compromete a Habermas, por de pronto, en otras dos posiciones fuertes, a saber: a) erige a lo que podemos llamar entendimiento liberal - la situación en que los antiguos amigo/ enemigo se convierten en meros oponentes - en la situación privilegiada y primigenia de todo discurso, obligándole a postular, en contraposición, un "uso del lenguaje distorsionado" o una "comunicación distorsionada" en que las reglas de la argumentación no se respeten y, por ende, se entorpezca el diálogo y se vele la finalidad de toda discusión pública ${ }^{18}$, y b) Habermas se compromete, al incardinar estas pretensiones de validez en el funcionamiento correcto o normal del lenguaje, con alguna suerte de gramática universal de contornos chomskianos ${ }^{19}$. El problema del primer punto es evidente: apelar a un uso propio y válido del lenguaje discursivo obliga a considerar el resto de usos (el estratégico, por ejemplo) como derivados pervertidos y equivocados. Pero aquí pensamos que lo complicado, al menos desde el segundo Wittgenstein, es defender que hay un uso preeminente en el lenguaje. No obstante, nos conformamos con señalar la problemática, pero no la desarrollaremos porque nos alejaría del recorrido político que pretendemos aquí. Del segundo caso podemos decir que resulta difícil aceptar que Habermas se desmarca de las tradiciones que han defendido nociones metafísicas de la naturaleza humana si atendemos a fragmentos como los que siguen: "El hecho de que gramaticalmente sea distinto creer que elegir parece más bien expresión de una característica de la condición humana que rasgo superficial de una con-

16 "Universalidad y verdad", en op. cit. pág. 92.

17 HABERMAS, J.: Facticidad y validez, ed. Trotta, Madrid, 2005, trad. e introd. de Manuel Jiménez Redondo, pág. 66.

18 "Todos los lenguajes ofrecen la posibilidad de distinguir entre lo que es verdad y lo que nosotros creemos que es verdad. En la pragmática de todo uso lingüístico hay incorporada la suposición de un mundo objetivo común" (HABERMAS, J.: Pensamiento postmetafísico, ed. Taurus [Humanidades], México, 1990, versión castellana de Manuel Jiménez Redondo, vid. cap. II: "El giro pragmático"). Lo que es verdad se ve favorecido por la pretensión de verdad (como una de las pretensiones de validez del lenguaje), mientras que lo que creemos que es verdad, ya alejado de las pretensiones de universalidad, caería dentro de los usos distorsionados de la comunicación. Es por ello que no podemos quedarnos en la inmanencia de la razón comunicativa, que podría condenarnos al provincianismo: hay que aceptarla como trascendente si queremos poseer reglas críticas para cuestionar actividades e instituciones.

19 Así, "algunos conceptos como verdad, racionalidad o justificación juegan siempre el mismo rol gramatical en todas las comunidades lingüísticas" (Ibíd.) 
vención lingüística" ${ }^{20}$. La crítica a estos pasajes depende, en última instancia, de si uno está de acuerdo con las tesis de Chomsky y sus seguidores acerca de la gramática universal o uno adopta un punto de vista distinto. Sea como fuere, lo que nos interesa a nuestros efectos es insinuar que Habermas no se libera de abstractas nociones tradicionales, de ascendencia metafísica, que rescatan la idea de una naturaleza humana accesible y de una racionalidad universal y ahistórica (aunque sutilmente trocadas en condición humana y razón comunicativa con un télos prefijado).

La estrategia de Habermas para defender la idea de validez universal, siguiendo esta estela, se basa en el conocido argumento de la "autocontradicción performativa". Este argumento reza como sigue: "cualquier participante que afirme o niegue la verdad de una afirmación y desee tomar parte en la argumentación que tiene por objeto justificar tal pretensión de validez estará obligado a aceptarlas [las pretensiones de la comunicación, entre las que se cuenta la de validez universal]" 21 . Y precisamente por esto (a saber: porque si entramos en una discusión ya estamos aceptando los presupuestos de la comunicación; p.e., al tratar de convencer a un racista de que los negros no pertenecen a una especie inferior utilizando argumentos biológicos, o al proponer, contra un machista, que las mujeres tienen la misma capacidad intelectual que los hombres apelando a argumentos similares, nuestro discurso pretenderá ser verdadero y válido universalmente), los presupuestos son incondicionales: "Los procesos fácticos de entendimiento llevan inscrito un momento de incondicionalidad - la validez que pretenden se distingue de la simple validez social"22. La validez universal se aúna a un momento incondicionado de los actos de habla argumentativos; y esta idea se completa y fortalece con algunas nociones gramaticales que salen en su auxilio. Quien no acepte este retrato, y aun así pretenda argumentar, caerá en una contradicción insalvable.

Ahora bien, ¿qué relación puede tener toda esta disquisición linguiística con el objetivo de justificar y defender la política democrática? ¿En qué ayudan las pretensiones de validez a la hora de criticar el autoritarismo? La respuesta a esta pregunta, más que la corrección o incorrección filosófica de la teoría de Habermas, es lo que dividirá definitivamente a ambos pensadores. Así, Habermas piensa que la defensa del entendimiento como télos del lenguaje es fundamental para la promoción de una sociedad democrática cada vez más amplia y genuina. Actúa en su obra precisamente como una actualización de la distinción ilustrada entre racionalidad y tradición: si se promociona el esquema intersubjetivo de "prácticas de justificación orientadas a pretensiones de verdad" poseeremos un criterio crítico para determinar la validez de algunas normas en contraposición a las que surgen sólo por "convención social" (tradición y provincianismo) o las que proceden de un "uso estratégico del lenguaje" (imposición de los fuertes). Si nos interesa la crítica de Rorty a esta estrategia es porque su lectura de Habermas apunta a que toda esta panorámica sigue siendo una convención de una sociedad determinada: "Tales prácticas están reguladas por ciertas convenciones sociales (...): aquellas convenciones de una sociedad todavía más democrática, tolerante, acomodada, rica y diversa que la nuestra" 23 .

20 Debate sobre...op. cit. pág. 40.

21 Facticidad y validez, op. cit. pág. 97.

22 El discurso filosófico... op. cit. pág. 382.

23 "Universalidad y verdad", en op. cit. pág. 96. 
El ideal de Habermas es, pues, a ojos de la relectura rortyana, el de una sociedad genuinamente democrática que profundiza en los logros de la sociedad europea de posguerra. Nada tienen que ver sus postulados con una razón comunicativa incondicionada, cuyo funcionamiento obliga a postular la noción de validez universal; sus tesis, antes bien, son una representación fidedigna del tipo de comunicación y el tipo de procedimiento legislativo que una sociedad verdaderamente democrática ha de adoptar y promocionar para funcionar. Habermas, por lo tanto, está elevando a concepto la circunstancia contingente de que hay un tipo determinado de sociedad que actúa, al menos en algunos momentos, tal y como la describe; pero no lo hace por ser más racional, ni por haber descubierto los presupuestos de la razón comunicativa. Habermas está describiendo la agradable vida democrática y su benéfico mecanismo de toma de decisiones. No es poco, pero no está describiendo la razón humana. Y precisamente por esto no puede resultar convincente a la hora de recoger acólitos: "si a un intolerante (...) le decimos que está obligado a tener pretensiones de validez que superen su contexto y que tengan por objeto la verdad, es probable que nos responda que eso es justamente lo que está haciendo" y, más adelante, "si le decimos que no puede tener tales pretensiones y (...) rechazar las personas que rechaza, luego es probable que no nos entienda" 24 . Es decir: no se puede convencer a un fanático religioso (o a un racista, o a un machista, etc.) de que se convierta al credo demócrata porque su práctica lingüística adolece de autocontradicción performativa ${ }^{25}$. La inmaculada pureza conceptual del bien engrasado arsenal habermasiano es irrelevante para la promoción de la democracia. Y si el argumento de la autocontradicción - que fundamenta la pertinencia de la noción de validez universal y su correlato incondicionado - no sirve para convencer (y ya vimos que convencer era el objetivo prioritario de la postura habermasiana), entonces no es válido para la promoción del pensamiento democrático. Lo que queda entonces de toda la propuesta de una comunicación libre de dominio es un ideal regulativo, propio de sociedades democráticas, que debiera favorecerse institucional y filosóficamente para que vaya incardinándose en el sentir y el pensar de los ciudadanos. Pero si Rorty está en lo cierto y este ideal es irrelevante a la hora de actuar democráticamente, entonces no tiene sentido defenderlo a capa y espada:

"Me doy perfecta cuenta de que la comunicación libre de dominio es tan sólo un ideal regulativo inalcanzable a nivel práctico. Ahora bien, un ideal regulativo sin relevancia de orden práctico sirve de poco" 26 .

¿Qué nos queda, entonces, de la propuesta habermasiana? Si su postura es ineficaz políticamente, y además un error teórico que resucita dogmas metafísicos felizmente enterrados, ¿cómo valorar su estrategia y cómo interpretar su aportación filosófica? Para Rorty,

24 Ibíd. pág. 98 y 99.

25 Rorty plantea el problema como sigue: "El principal problema es saber si ha habido nunca nadie que se haya creído la acusación de estar cometiendo una autocontradicción performativa". Ibíd.

26 Ibíd. pág. 131. La alternativa rortyana es explícitamente polémica. Tras admitir que él prefiere, con Habermas, la política democrática a cualquier otro tipo de modelo, su consciente abandono de cualquier justificación basada en la razón comunicativa le lleva a concluir lo siguiente: "Tengo la impresión de ser tan provinciano y contextualista como esos profesores nazis que obligaban a leer Der Stürmer, la única diferencia es que yo sirvo a una mejor causa. Provengo de una mejor provincia”. ¿Cómo defender que su provincia es mejor sin atender a criterios racionales? Ése será el reto de la propuesta rortyana. 
recurriendo a Lyotard, lo de Habermas no es sino una nueva "metanarrativa", barnizada con tintes metafísicos, que tiene por objeto la emancipación. Objetivo tan noble no ha de ser desechado; pero estrategia tan débil, sí. Aunque, en el fondo, tal vez Rorty y Habermas no sean tan diferentes: "Tengo a Derrida por el más intrigante e ingenioso de los filósofos contemporáneos, y a Habermas por el más útil socialmente"27.

\section{La respuesta autoafirmativa de Rorty}

Comenzamos este trabajo defendiendo a Rorty como alguien que, consciente de los límites de la socialdemocracia, en vez de añorar nociones ahistóricas y trascendentales para abordar su justificación (estrategia que, si hemos logrado nuestro propósito, podemos ya reconocer en Habermas), toma conciencia de haber tocado techo y actúa en consecuencia. La democracia, para Rorty, no puede basarse en esa voluntad de justificación indisociable de la verdad. Si la justificación se entiende como el correlato de una teoría de la racionalidad, Rorty verá siempre en este enfoque la añoranza de una luz blanquecina más pura y la búsqueda de lo que Nietzsche llamara confort metafísico. Su estrategia, en cambio, apelará al sentimiento y la utilidad en vez de a la razón; propondrá un modo de defensa de los valores democráticos que interpele a su carácter inclusivo y a las consecuencias provechosas de su asunción. No es éste el lugar de exponer in extenso la filosofía política del autor pragmatista; pero sí será conveniente explicar, aunque sea brevemente, aquellos puntos en los que se opone a Habermas, pues ello nos servirá para entender al fin su convicción de que la democracia tiene prioridad sobre la filosofía (y, por lo tanto, la provocativa afirmación de que el filósofo tiene un papel irrisorio en la promoción de la misma).

Quizá una buena forma de adentrarnos en este punto sea rescatar un párrafo del jurista Hans Kelsen, representante del positivismo jurídico, que tematiza a la perfección el escenario que acepta Rorty:

"Precisamente en ese punto donde se diría que se pierde toda posibilidad de justificar la democracia (por no ser posible apelar a verdades prácticas), justo en ese punto es donde cabe iniciar su defensa. Precisamente quien considera cerrada al conocimiento humano la verdad metafísica, es decir, la verdad absoluta y los valores absolutos, tiene que tener por posibles no sólo la opinión propia, sino también la opinión ajena, y la opuesta. De ahí que el "relativismo" sea la cosmovisión que la idea democrática presupone. La democracia da igual valor a la voluntad política de cualquiera, al igual que respeta también toda fe política, pues la voluntad política no es sino la expresión de ella. Por eso da a toda opinión política la misma libertad de expresarse y de hacerse valer ganándose en competencia libre la voluntad de los hombres"28.

Es decir: abandonada la idea de Verdad Única, la democracia ha de tolerar estructuralmente cualesquiera alternativas y opiniones gestadas en su seno. El relativismo es, pues, el

27 "Habermas, Derrida...” op. cit. pág. 341. La cursiva es nuestra.

28 KELSEN, H.: "Esencia y valor de la democracia", citado en el prólogo de Manuel Jiménez Redondo a Aclaraciones a la ética del discurso, op. cit. 
punto de partida de la democracia. El problema surge al pretender que este dato irrecusable se articule en una teoría de la democracia universalmente válida, pues entonces estaría elevando a Verdad Única éste su carácter relativista, y si así ocurriera estaría renunciando a su función más valiosa. El de Habermas puede leerse como un intento de elevar a principio y concepto esta función política de la democracia, pero los peligros de dogmatizar esta función y convertirla en un residuo metafísico que pudiera interferir en el principio de libertad son, a juicio de Rorty, patentes. La democracia, para justificarse, no puede hacer otra cosa que imponerse como este régimen de ausencia de Verdad Última, sostenido por la voluntad (posiblemente, general) de sus ciudadanos de seguir viviendo en un régimen de libertades. Por eso, Rorty opondrá a la "fundamentación" habermasiana una "autoafirmación": la democracia liberal se fundamenta a sí misma - si queremos decirlo así - sin necesidad de recurrir a ningún tipo de teoría de la racionalidad, en tanto que régimen de libertad al que la mayoría de ciudadanos da su tácita aprobación ${ }^{29}$. Una buena exposición de esta autoafirmación la encontramos en las siguientes líneas:

"La idea de una nueva comunidad que se crea a sí misma, unida no tanto por el conocimiento de unas mismas verdades cuanto por el hecho de compartir unas mismas esperanzas inclusivistas, generosas y democráticas"30.

Si hay un modelo de sociedad estructuralmente inclusivo, por carecer de una Verdad Última en la que validarse, ése es el liberal-democrático. Así, ese régimen que se fundamenta a sí mismo por resultar satisfactorio y agradable ha sido un "mero y afortunado accidente" 31 - porque no es expresión de la naturaleza racional de la especie humana, sino una contingencia que podría no haber ocurrido - que conviene defender con uñas y dientes. Pero su defensa no puede ser una mera reflexión teorética acerca del progreso y la universalidad, puesto que ello no resultaría ni convincente ni beneficioso. La propuesta rortyana, pues, consiste en reemplazar "la idea de obligación moral universal de respeto a la dignidad humana (...) por la idea de lealtad a un grupo muy amplio: la especie humana"32. Creemos que el núcleo de su oposición a Habermas se concentra en un fragmento de su artículo "La justicia como lealtad ampliada", de modo que lo reproducimos in extenso:

"La cuestión de si las demandas de reforma que las sociedades liberales occidentales hacen al resto del mundo son hechas en nombre de algo no occidental (algo como la moralidad, la humanidad o la racionalidad) o bien son simplemente expresiones de lealtad a concepciones de la justicia occidentales y locales. Habermas diría que son lo primero, yo diría que son más bien lo segundo, pero no por ello son peores"33.

29 En este punto, Rorty se apoya en la noción rawlsiana de overlapping consensus, en tanto que el consenso solapado de los ciudadanos de una sociedad democrática fundamenta y justifica por sí solo el régimen democrático-liberal.

30 "Universalidad y verdad", en op. cit., pág. 85.

31 Ibíd., pág. 112.

32 "La justicia como..." en op.cit. pág. 109.

33 Ibíd.pág. 112. 
Lo que conviene, a juicio de Rorty, es ser "francamente etnocéntrico" 34 y admitir que defendemos nuestras posiciones porque somos leales a nuestra cultura y a nuestro juego de lenguaje democrático. Vencer sin convencer, pero no a la fuerza: se trata de no intentar asimilar a los otros en función de un criterio de racionalidad que pretendidamente no alcanzan a comprender por no disponer de la información o la educación necesarias; por el contrario, se trata de vencer ofreciendo al resto de sociedades que prueben el estilo de vida de un sistema que se autojustifica sin reglas extrínsecas y se legitima como régimen de no-verdad. Y no por ello esta sociedad sería menos racional que la habermasiana. Sí sería, en cambio, mucho más sincera y honesta.

\section{Corolario: Notas sobre la irrelevancia de la teoría}

Todo este excurso se justifica en la medida en que su polémica con Habermas puede hacernos capaces de entender su afirmación de la irrelevancia de la filosofía en cuanto al compromiso público respecta. $\mathrm{O}$, lo que es lo mismo, su consabida tesis de que la democracia tiene prioridad sobre la filosofía. Hemos visto lo que no debe postular un intelectual a la hora de validar las posiciones democráticas; y hemos subrayado, además, que entre otras no debe hacerlo porque la democracia no necesita una legitimación última: basta con su constante autoafirmación. Si esto es así, la función del filósofo ya no puede ser la que se deduce de las afirmaciones habermasianas: el aporte teórico de una justificación capaz de aunar dos aspectos que en el neopragmatismo de Rorty están suficientemente demarcados, y que son la naturaleza humana (o su comprensión como seres racionales) y la justicia. Una vez roto este vínculo - es decir: una vez demostrado que hablar de "naturaleza humana" presupone asunciones metafísicas indeseables -, la búsqueda intelectual de un puente que una ambas esferas se revela como una actividad irrelevante, incapaz de conducir a consecuencias prácticas.

El corolario de este cambio de perspectiva será, como hemos dicho, la consagración de la democracia como un sistema para la perfectibilidad del cual la filosofía no tiene mucho que aportar. Lo prioritario no es, pues, postular un esquema filosófico acerca de la racionalidad humana y después proyectar qué tipo de instituciones y prácticas se derivarían del mismo; la única forma responsable de defender filosóficamente la democracia consiste en aceptar esta última como primordial, y deducir de ella el tipo de filosofía (no entendida ya como "teoría”, sino como "articulación”) que debiera adoptarse. Una sociedad así actuará como sigue:

"Se acostumbrará a la idea de que la política social no necesita otra autoridad que la que se establece por medio de un acuerdo exitoso entre individuos, unos individuos que se reconocen herederos de las mismas tradiciones históricas y enfrentados a los mismos problemas (...) Cuando una sociedad de ese tipo delibere (...) tenderá a prescindir de aquellos derivados de explicaciones filosóficas del yo o de la racionalidad"35.

34 Así se expresa, por ejemplo, en "Habermas y Lyotard...", en op. cit., pág. 261.

35 RORTY, R. "La prioridad de la democracia sobre la filosofía”, en Objetividad, relativismo... op. cit. pág. 251. 
La aceptación de esta descripción (la única plausible para Rorty si se desechan los intentos habermasianos de fundamentar el sistema democrático) relega la práctica filosófica a la misma esfera que el desencantamiento del mundo destinara a la religión: la privatiza. La tesis es lo suficientemente fuerte como para dar carpetazo definitivo a la imagen del intelectual que comienza a resquebrajarse a principios del s. XX: la filosofía es irrelevante e innecesaria para la política social, esto es... ¡para transformar el mundo! (a mejor, se entiende). Por eso en otro lugar ${ }^{36}$ redondeará esta idea diciendo que el ámbito de deliberación pública y de mejora de la justicia social ha de estar dominado por un vocabulario "banal" y "ateórico", centrándose en lo "concreto" y abandonando los "movimientos" para sustituirlos por las "campañas" (finitas, contingentes, parciales, y en absoluto determinadas por la imbricación entre la propia identidad y los objetivos políticos). Esta es la única forma que ve nuestro autor de desprenderse de lo que, con Kierkegaard, llama la "pasión de infinito", y su condición de posibilidad es la renuncia del filósofo a participar en la deliberación pública precisamente qua filósofo (sí podrá hacerlo, como es obvio, en tanto que ciudadano). La filosofía queda, en consecuencia, encarcelada en la esfera de la autocreación irónica privada. Así se logrará dar cumplimiento a su desencantada concepción y "abandonar la convicción de que los intelectuales estamos notablemente mejor capacitados que nuestros conciudadanos para poner en pensamiento nuestro tiempo" ${ }^{37}$. La ciudadanía - en la forma preferible del ironista autoconsciente - ha de sustituir al intelectual. Toda vanguardia, filosófica o cultural, ha de ser destruida.

Sea como fuere, antes de concluir es necesario matizar que estas dos esferas que Rorty consagra como separadas no hay que entenderlas como dos compartimentos con límites bien definidos; por el contrario, los límites entre lo público y lo privado son "borrosos" y están en "constante cambio"38. De lo que se trata, pues, es de evitar que las confusiones filosóficas acaben amalgamando dos ámbitos de creencia que conviene separar: 1) El compuesto por las creencias y deseos compartidos por los miembros de una determinada comunidad (en este caso, la liberal), y 2) aquellas creencias y deseos que son puramente idiosincrásicos. La primera parte es la que prescinde de las ultimidades existenciales de cada individuo y constituye el ágora pública de toma de decisiones; el segundo, por tanto, es el que recoge aquel entramado de creencias y deseos que el individuo, para conformar su identidad, considera relevantes. Una vez demostrado que no hay ningún puente necesario entre ambas esferas (lo que no quiere decir, por cierto, que algunos individuos no actúen como si ese vínculo existiera e hicieran depender su acción política de su idiosincrasia, y a la inversa), lo más productivo para la transformación social es el tipo de carácter recomendado —el irónicoy la asunción de un vocabulario compartido - el banal y ateórico - que reniegue de las creencias y deseos personales a la hora de paliar las desigualdades e injusticias. Sólo así las rojizas luces de la habitación democrática podrán brillar con toda su fuerza.

36 Cf. "Movimientos y campañas”, en RORTY, R. Pragmatismo y política, ed. Paidós, Barcelona: 1998.

37 RORTY, R.: "El final del leninismo, Havel y la esperanza social”, en Verdad y Progreso [escritos filosóficos III], ed. Paidós, Barcelona, 2000, pág. 286.

38 Cfr. al respecto su emocionante artículo autobiográfico "Trotsky y las orquídeas silvestres", donde se matiza la borrosidad de los límites en el binomio público/privado, y se subraya la marca idiosincrásica del segundo término. 


\section{Bibliografía}

RORTY, R.

- "Universalidad y verdad", en El pragmatismo, una versión, ed. Ariel, Barcelona, 2000.

- "La justicia como lealtad ampliada", en Pragmatismo y política, ed. Paidós, Barcelona, 1998.

- "Liberalismo burgués posmoderno", en Objetividad, relativismo y verdad, ed. Paidós, Barcelona, 1996.

- "Habermas y Lyotard sobre la posmodernidad", en Habermas y la modernidad, ed. Cátedra [colección teorema], Madrid, 1988.

- "Habermas, Derrida y las funciones de la filosofía", en Verdad y progreso, [escritos filosóficos 3], ed. Paidós, Barcelona, 2000.

- "La prioridad de la democracia sobre la filosofía", en Objetividad, relativismo... op. cit.

- "Movimientos y campañas", en Pragmatismo y política, ed. Paidós, Barcelona: 1998.

- "El final del leninismo, Havel y la esperanza social", en Verdad y Progreso [escritos filosóficos III], ed. Paidós, Barcelona, 2000.

HABERMAS, J.

- Aclaraciones a la ética del discurso, trad. e introd. de Manuel Jiménez Redondo, ed. El Cid Editor [recurso electrónico de la biblioteca de la UV], Santa fe, 2004.

- "El manejo de las contingencias y el retorno del historicismo", en Debate sobre la situación de la filosofía, editado por Jósef Niznik y John T. Sanders, ed. Cátedra (colección teorema), Madrid, 2000.

- El discurso filosófico de la modernidad, ed. Taurus (Humanidades), Madrid, 1993.

- Facticidad y validez, ed. Trotta, Madrid, 2005, trad. e introd. de Manuel Jiménez Redondo.

- Pensamiento postmetafísico, ed. Taurus [Humanidades], México, 1990, versión castellana de Manuel Jiménez Redondo.

\section{OTROS}

- WITTGENSTEIN, L.: Luz y sombra. Una vivencia (-sueño) y un fragmento epistolar, trad. de Isidoro Reguera, ed. Pre-textos, Valencia, 2006.

- KELSEN, H.: "Esencia y valor de la democracia", citado en el prólogo de Manuel Jiménez Redondo a Aclaraciones a la ética del discurso, op. cit.

- HABERMAS, J., RORTY, R., KOLAKOWSKI, L., Debate sobre la situación de la filosofía, editado por Jósef Niznik y John T. Sanders, ed. Cátedra (colección teorema), Madrid, 2000. 
